\title{
CHARACTERISTICS OF PREGNANCY, DELIVERY AND THE POSTPARTUM PERIOD IN PREGNANT WOMEN DIAGNOSED WITH GESTATIONAL DIABETES MELLITUS
}

\author{
Nikola Jovic $^{1}$, Mirjana Varjacic ${ }^{1,2}$, Ana Zivanovic Nenadovic ${ }^{2}$ \\ ${ }^{1}$ Faculty of Medical Sciences, Kragujevac, Kragujevac, Serbia \\ ${ }^{2}$ Gynaecology and Obstetrics Clinic, Clinical Centre Kragujevac, Kragujevac, Srbija
}

\author{
KARAKTERISTIKE TRUDNOĆE, POROĐAJA \\ I POSTPARTALNOG PERIODA TRUDNICA \\ SA DIJAGNOZOM GESTACIJSKOG DIJABETES MELITUSA \\ Nikola Jović ${ }^{1}$, Mirjana Varjačić ${ }^{1,2}$, Ana Živanović Nenadović ${ }^{2}$ \\ ${ }^{1}$ Fakultet medicinskih nauka, Univerzitet u Kragujevcu, Kragujevac, Srbija \\ ${ }^{2}$ Klinika za ginekologiju i akušerstvo, Klinički centar Kragujevac, Kragujevac, Srbija
}

Received / Primljen: 21.12.2015.

Accepted / Prihvaćen: 17.01.2016.

\begin{abstract}
Gestational diabetes mellitus refers to both transient diabetes that arises during pregnancy and is restored postpartum as well as forms of the disease that arise for the first time during pregnancy and persistently exhibit insulin-dependence (type 1) after childbirth. The basis for the development of gestational diabetes is the existence of insulin resistance.

Our target population was pregnant women between 20 and 46 years of age who were diagnosed with gestational diabetes (after the 24th week of pregnancy) and who were treated at the Department of Pathology of Pregnancy, Clinical Centre Kragujevac. During the research period, data were collected from 95 pregnant women with diagnosed gestational diabetes. In 3 women, the pregnancy ended in intrauterine foetal demise, and the study was continued with 92 subjects. This is a crosssectional, retrospective and observational study.

The average age of the examinees in our sample is 31.6 years. A total of $77.89 \%$ of the examinees achieved normoglycaemia exclusively via a hygienic dietary regimen. However, $27.2 \%$ of the subjects exhibited comorbidities in addition to gestational diabetes, which further complicated the pregnancy. A total of $70.7 \%$ examinees delivered between the 37 th and 40th week of gestation. Vaginal delivery was dominant, with episiotomy in almost half the cases. The average body weight of newborns from pregnancies complicated by gestational diabetes was 3587.07 grams, which is very close to the macrosomia limit of 4000 grams.

The timely detection of gestational diabetes and an adequate treatment of pregnant women can prevent the occurrence of foetal macrosomia as the primary complication of these pregnancies. Pregnancy complicated by gestational diabetes is not necessarily an indication for a Caesarean section.
\end{abstract}

Keywords: pregnancy, gestational diabetes, delivery

\section{SAŽETAK}

Gestacijki dijabetes melitus odnosi se na tipove dijabetesa nastale u trudnoći sa prolaznim karakterom postpartalno, ali i na oblike ove bolesti koji se prvi put otkrivaju u trudnoći, a nastavljaju da perzistiraju i nakon porođaja kao insulin zavisni tipovi (tip 1).

Ciljana populacija bile su trudnice starosti izmedu 20 i 46 godina sa dijagnostikovanim gestacijskim dijabetesom (nakon 24. nedelje trudnoće) lečene na odeljenju patologije trudnoće KC Kragujevac. U periodu ispitivanja podaci su prikupnjeni od 95 trudnica sa dijagnozom gestacijskog dijabetesa. Zanemareni su podaci prikupljeni od 3 trudnice sa intrauterinom smrti ploda, a studija je nastavljena sa 92 trudnice koje imaju dijagnozu gestacijskog dijabetes melitusa. Studija koju smo sproveli je studija preseka, retrospektivna i opservaciona.

Prosečna starost ispitanica u uzorku iznosi 31.6 godina. Većina trudnica su bile prvorotke. $77.89 \%$ trudnica je stanje normoglikemije ostarivalo higijensko dijetetskim režimom. Prateće dijagnoze koje su trudnoću komplikovanu gestacijskim dijabetesom dodatno komplikovale imalo je $27.2 \%$ trudnica. $70.7 \%$ trudnica se porodilo izmedu 37. i 40. nedelje gestacije. Dominirao je vaginalni način porođaja uz epiziotomiju kod skoro polovine ispitanica.

Pravovremeno otkrivanje gestacijskog dijabetesa $i$ adekvatno lečenje trudnica sprečiće nastanak makrozomije fetusa kao osnovne komplikacije ovih trudnoće. Trudnoća komplikovana gestacijskim dijabetesom nije sama po sebi indikacija za carski rez.

Ključne reči: trudnoća, gestacijski dijabetes, porođaj 


\section{INTRODUCTION}

Metzger defines gestational diabetes mellitus (GDM) as "any degree of glucose intolerance with onset or first recognition during pregnancy"(1). This definition does not encompass cases of undiagnosed diabetes in which the disease was present before pregnancy. For this reason, the boundary between comorbidities associated with diabetes during pregnancy and gestational diabetes is blurred (2). Gestational diabetes mellitus refers to those types of diabetes that arise during pregnancy with transient character postpartum, but it also refers to the forms of disease that arise for the first time during pregnancy but continue to persist even after childbirth as insulin-dependent types (type 1). Gestational diabetes mellitus refers to both transient diabetes that arises during pregnancy and is restored postpartum as well as forms of the disease that arise for the first time during pregnancy and persistently exhibit type 1 insulin-dependence after childbirth (3).

Positive correlations between GDM and obesity, as well as glucose-intolerance and diabetes mellitus type 2, have led to an increase in the prevalence of this disease on a global level (4).Although the prevalence of the disease varies by nationality and ethnicity (1-28\%), recent studies have shown that it is taking on an epidemic character (5). The latest IDF (International Diabetes Federation) findings show that one out of six pregnant women (16.8\%) has some type of hyperglycaemia and that $16 \%$ of these cases are due to insulin-dependent (type 1) or noninsulin-dependent (type 2) diabetes mellitus; the remaining $84 \%$ of cases are due to gestational diabetes (6).

While both general and gestational diabetes are predominantly categorized as a disorder of carbohydrate metabolism, the mechanisms of this condition are complex, with lipid and protein metabolisms being affected as well (3). The basis for the development of gestational diabetes is a state of insulin resistance (7). It contributes to weight gain during pregnancy due to fat accumulation and increased calorie intake as well as reduced physical activity (4-7). The other pathophysiological aspects contributing to gestational diabetes relate to altered hormonal expressions. The placental hormones are the primary drivers of gestational diabetes, which is supported by the fact that insulin resistance diminishes after placental expulsion (8).

Human placental lactogen, which is secreted during pregnancy, reduces glucose utilization and intensifies lipolysis (8). This causes an increased level of free fatty acids, which contributes to insulin resistance (8-9). Insulin resistance results in further exhaustion of beta cells in the islets of Langerhans, thus reducing their productive capacity $(9,10)$.

The placenta develops during the pre-embryonic and embryonic periods. Therefore, manifestation of gestational diabetes rarely occurs during the first trimester of pregnancy (11). Manifestations during the second and third trimesters (usually after the $24^{\text {th }}$ week of pregnancy) are evident due to the production of human placental lactogen, which is the insulin antagonist (the antagonist of the growth hormone, cortisol). Additionally, oestrogen and progesterone also play an indisputable role $(11,12)$. Prior to placental signalling, developmental changes occur in the mother's body, and hyperglycaemia and hypoinsulinaemia are manifestations of these placental signalling processes (12).

As a result of insulin resistance, glucose passes the placental barrier and causes hyperinsulinemia in the foetus. As insulin is the main growth factor during the foetal period, hyperinsulinemia causes accelerated growth of the foetus and subsequent macrosomia $(9,11)$.

\section{Research Goals:}

- To determine whether a correlation exists between age and parity of subjects and incidence of gestational diabetes

- To determine whether establishing normoglycaemia in subjects can be achieved primarily through a hygienicdietary regimen

- To determine the influence of comorbidities on pregnancy outcomes in women with gestational diabetes

- To determine whether vaginal delivery is dominant in pregnancies with gestational diabetes

- To determine whether a correlation exists between foetal macrosomia and gestational diabetes and to determine the effectiveness of treatmentTo demonstrate whether gestational diabetes persists into the postpartum period in up to $5 \%$ of cases

\section{MATERIALS AND METHODS}

The research we have conducted is a cross-sectional, retrospective and observational study. The data were collected by labour, newborn, and postpartum chart reviews. After the input of appropriate data, we processed the data in the SPSS program, version 20.

We recruited pregnant women between 20 and 46 years of age who were diagnosed with gestational diabetes (after the 24th week of pregnancy), who were treated at the Department of Pathology of Pregnancy, Clinical Centre (CC), Kragujevac, and who gave birth at the Maternity Ward, CC Kragujevac, from January 1st 2013 through June 30th 2015.

For didactic reasons, the data were divided into four categories: general information of the examinees as well as data related to the prepartum, intrapartum, and postpartum periods.

The general information included the age of the subjects, the length of the pregnancy, the outcome of the pregnancy and whether the conception was done naturally or by artificial insemination (IVF/ET - in vitro fertilization/ embryo transfer). Pregnant women were stratified into four groups that analysed parity: primipara, secundipara, tripara, and multipara (more than three childbirths).

During the prepartum period, the diagnosis and treatment of diabetes is emphasized at doctors' examinations because it greatly contributes to pregnancy risk. Based on the method of treatment, the subjects were divided into 
two groups: those who achieved normoglycaemia by a hygienic-dietary regimen (HDR) and those who were concomitantly treated with insulin therapy. The World Health Organization (WHO) recommends that the cut-off for hyperglycaemia in blood to be set at $6.1 \mathrm{mmol} / \mathrm{L}$. The subjects were further divided into those with or without the following comorbidities: thrombophilia, high blood pressure, placental abruption, and a multiples pregnancy.

The intrapartum period includes the period of childbirth. The time of delivery was analysed (preterm delivery - before 36.6 weeks of pregnancy, term - from 37.0 to 39.6 weeks of pregnancy, postterm - after 40.0 weeks of pregnancy). Additionally, the method of delivery (spontaneous vaginal delivery, vaginal delivery with episiotomy, and delivery by Caesarean section) and the Apgar scores (1-9) were assessed as well as the average body weight, height, and head circumference of the foetus.

The postpartum period includes follow-up through 40 days after childbirth, with the intent to detect persistent hyperglycaemia in the subjects. Subjects were divided into two groups: those who had persistent hyperglycaemia and those whose hyperglycaemia had resolved.

\section{RESULTS}

During the study period, the data from 95 gestational diabetic pregnant subjects were collected. Ninety-two women $(96.84 \%)$ carried their pregnancy to live childbirth, and for 3 women, the pregnancy ended in intrauterine foetal demise (3.16\%). The data were then analysed to include the remaining 92 subjects as the complete dataset (representing $100 \%$ of the subjects).The average age of subjects was 31.6 years old, with ages ranging from 20-46 years. Natural conception occurred in 90 cases, while two cases were impregnated using IVF/ET methods.

Fifty (54.3\%) subjects were primipara, 32 (34.8\%) subjects were secundipara, 6 (6.5\%) subjects were tripara, and 4 (4.3\%) subjects or were multipara (as shown in Tables 1 and 2).

Seventy-four (77.89\%) of the examinees achieved normoglycaemia by a hygienic-dietary regimen, while for 18 $(22.11 \%)$ of the examinees, insulin therapy was necessary to return the glycaemia to balanced levels (Table 1).

Twenty-five (27.2\%) of the subjects exhibited additional complications due to comorbidities. The most frequent diagnosis was pre-pregnancy or pregnancy-induced hypertension (17 women [18.48\%]), thrombophilia (12 women [13.04\%]), and bleeding immediately prior to childbirth or placental abruption (3 women [3.26\%]). There was only one case of a multiples pregnancy $(1.09 \%$ of the study population). In almost $30 \%$ of the cases, the pregnancy was complicated by more than one comorbidity (Table 3 ).

In regard to the intrapartum period, 65 (70.7\%) examinees delivered between the 37 th and 40th week of gestation. Preterm delivery (before the 37th week) occurred in $10(10.9 \%)$ of women examinees, while postterm pregnancy was present in 17 women (18.5\%) (Table 4).
Table 1. Descriptive table*

\begin{tabular}{|c|c|c|}
\hline & $\begin{array}{c}\text { Number of } \\
\text { examinees }\end{array}$ & $\%$ \\
\hline primipara & 50 & 54.3 \\
\hline multipara (>one childbirth) & 42 & 45.7 \\
\hline hygienic-dietary regimen & 74 & 77.89 \\
\hline + insulin therapy & 18 & 22.11 \\
\hline without accompanying diagnosis & 67 & 72.8 \\
\hline with accompanying diagnosis & 25 & 27.2 \\
\hline full term delivery & 65 & 70.7 \\
\hline pre- or postterm delivery & 27 & 29.3 \\
\hline vaginal delivery & 58 & 63 \\
\hline Caesarean section & 34 & 37 \\
\hline
\end{tabular}

Table 2. Parity of research examinees

\begin{tabular}{|c|c|c|}
\hline \multicolumn{3}{|c|}{ parity of research examinees } \\
\hline Parity & number of examinees & $\%$ \\
\hline Primipara & 50 & 54.3 \\
\hline Secundipara & 32 & 34.8 \\
\hline Tripara & 6 & 6.5 \\
\hline Multipara & 4 & 4.3 \\
\hline Total & 92 & 100 \\
\hline
\end{tabular}

Table 3. Accompanying diagnosis which complicate the pregnancy

\begin{tabular}{|c|c|c|c|c|}
\hline & ompar & g diagnosis which c & ate & nancy \\
\hline \multirow{7}{*}{ 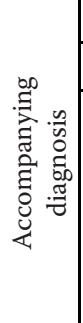 } & \multicolumn{4}{|c|}{ Examinees } \\
\hline & & Not present & 67 & $72.8 \%$ \\
\hline & \multirow{5}{*}{ Present } & hypertension & 25 & $27.2 \%$ \\
\hline & & thrombophilia & 12 & $13.04 \%$ \\
\hline & & abruption & 3 & $3.26 \%$ \\
\hline & & multiple pregnancy & 1 & $1.09 \%$ \\
\hline & & multiple diagnosis & 27 & $29.8 \%$ \\
\hline
\end{tabular}

Table 4. Time of labour in terms of gestational age

\begin{tabular}{|c|c|c|}
\hline \multicolumn{3}{|c|}{ Time of labour } \\
\hline & number examinees & $\%$ \\
\hline preterm & 10 & 10.9 \\
\hline full term & 65 & 70.7 \\
\hline postterm & 17 & 18.5 \\
\hline
\end{tabular}

Table 5. Delivery

\begin{tabular}{|c|c|c|}
\hline \multicolumn{3}{|c|}{ Delivery } \\
\hline & number of examinees & $\%$ \\
\hline spontaneous & 17 & 18.5 \\
\hline episiotomy & 41 & 44.6 \\
\hline Caesarean section & 34 & 37.0 \\
\hline
\end{tabular}

The modes of delivery (Table 5) had the following characteristics: 41 (44.6\%) women had a vaginal delivery, with episiotomy in almost half the cases; 17 (18.5\%) women had 


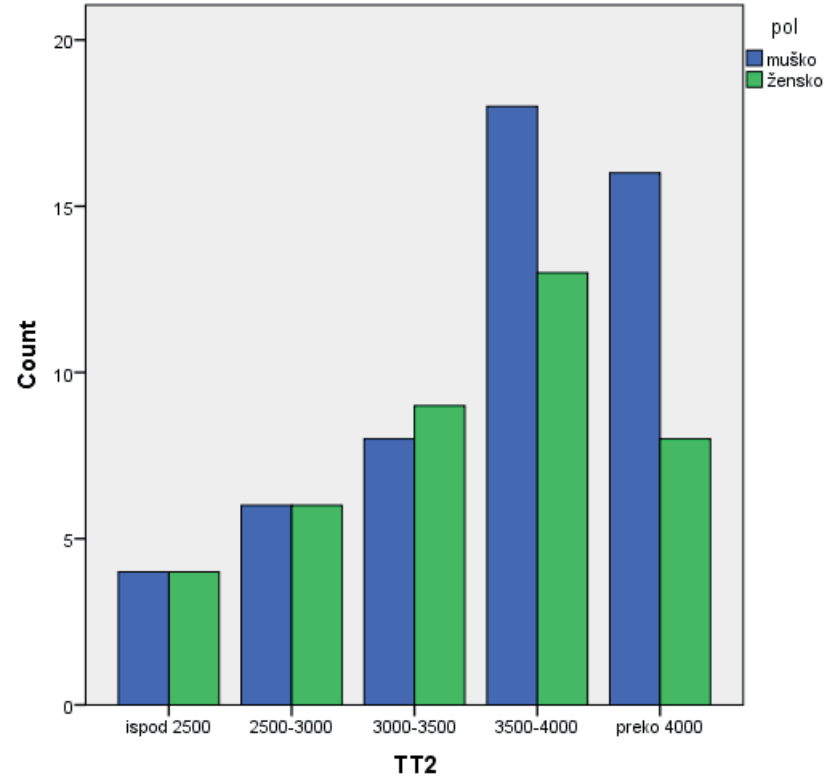

Table 2. Parity of research examinees

a spontaneous vaginal delivery; and 34 (37.0\%) women had a Caesarean section.

The average body weight of newborns from pregnancies complicated by gestational diabetes was 3587.07 grams, which is very close to the macrosomia limit of 4000 grams. The largest newborn weighed 4950 grams. Despite this finding, the Apgar scores in the first minute were relatively high (8.63) and did not significantly change during the fifth minute. The average length of newborns was 55.1 $\mathrm{cm}$, with an average head circumference of $34.72 \mathrm{~cm}$. A total of $56.5 \%$ of the newborns were male, and $43.5 \%$ were female, as shown in Graph 1.

An analysis of the data indicated that elevated glycaemia measurements during the 12-hour glycaemic profile (tested with $75 \mathrm{mg}$ of glucose) occurred in 4 (4.34\%) of the cases.

\section{DISCUSSION}

Analysis of these results indicated that the age of the subject did not predict the emergence of gestational diabetes. Contrary to expectations, the average age of examinees in our sample was 31.6 years, which was closer to the age of our youngest examinee (20 years) than our oldest examinee (46 years). More than $50 \%$ of examinees were recruited from the primipara category, which is contrary to previous reports indicating that gestational diabetes is more frequent from multipara subjects $(2,4)$.

Seventy-four (77.89\%) examinees achieved normoglycaemia exclusively by following a hygienic-dietary regimen. These results support previous studies. For example, Crowther et al. demonstrated that normalization of glycaemia in pregnant women with gestational diabetes was successfully achieved by the hygienic-dietary regimen in $75-80 \%$ of the cases (12).
Almost a quarter of examinees had an accompanying comorbidity that further increased pregnancy risk. The dominant co-diagnosis was hypertension, and more than one third of examinees (29.8\%) had at least two or more accompanying diagnoses. Analysing the data, it was determined that surgical delivery was required for the majority of subjects with comorbidities.

A total of $70.7 \%$ of women had a full-term pregnancy, and most of the deliveries were vaginal with an episiotomy. It is important to note that gestational diabetes, although it contributes to foetal macrosomia (12), is not necessarily an indication for Caesarean section. The main indications for Caesarean section were the following:

- Malpresentation of the foetus

- Previous Caesarean sections

- Comorbidities in mothers

- Placental abruption

- Artificial insemination (13)

The above listed indications for a surgical delivery are the same as those for a normoglycaemic pregnancy. The frequency of surgical delivery in pregnant women with gestational diabetes was greater than the usual percentage of Caesarean sections. This increased rate may be caused by the frequency of accompanying diseases, comorbidities, and complications from diabetes.

The body weight of newborns serves as a proxy for whether gestational diabetes was treated adequately during pregnancy. Gestational diabetic pregnancies specifically result in giving birth to macrosomic newborns, which can be defined as either $4000 \mathrm{~g}$ or babies that are too large for their given gestational age (i.e., over the 90th percentile) $(6,12)$. Early detection of gestational diabetes and adequate treatment of pregnant women can prevent the occurrence foetal macrosomia.

In this study, 25 pregnant women who were diagnosed with gestational diabetes gave birth to children whose body weight was over 4000 g. This statistic comprises $27.12 \%$, which is slightly higher than the body weight averages reported in previous studies. For example, two papers found that approximately $20 \%$ of macrosomic newborns are from gestational diabetic pregnancies $(4,12)$.

Interestingly, a more detailed analysis of the anamnesis of patients who gave birth to macrosomic babies found that they had difficulty regulating glycaemia levels during pregnancy using standard therapeutic procedures. These data suggest that maternal hyperglycaemia and subsequent foetal hyperinsulinemia was a longstanding issue.

In these data, no statistically relevant differences were found in the body weight, head circumference or sex of the newborns. Additionally, the Apgar score of 8.63 showed that this population did not deviate significantly in comparison with newborns from uncomplicated pregnancies.

Gilmartin found that in 3-5\% of gestational diabetic pregnancies, the condition persists into the postpartum period (4). For this study, a test with $75 \mathrm{mg}$ of glucose was given. The results indicated that one or more measure- 
ments of glycaemia within the parameters of a 12-hour glycaemic profile were elevated in 4 (4.34\%) of the subjects.

\section{CONCLUSION}

The results from the first aim of our study were contradictory to the previous literature. We did not find a positive correlation between the age of the subjects and the occurrence of gestational diabetes. Additionally, the largest percentage of examinees in our research were recruited from the primipara category.

Our findings suggest that in two-thirds of cases, normoglycaemia can be achieved in pregnancies complicated by gestational diabetes when a subject adheres to a hygienic-dietary regimen, which is similar to previous results. In our patient population, the physiological values of glycaemia were achieved by modified nutrition and moderate physical activity.

Pregnancy complicated by gestational diabetes is not necessarily an indication for a Caesarean section. In this study population, the frequency of surgical delivery in pregnant women with gestational diabetes was greater than the reference distribution from the general population. In our population, the main causes for these Caesarean sections were accompanying diagnoses, comorbidities and diabetes complications.

Timely detection of gestational diabetes and adequate treatment of pregnant women can prevent the occurrence of foetal macrosomia as the primary complication resulting from these pregnancies. The data analysed in our research show a slightly greater frequency of macrosomic newborns compared to the reference literature, even with adequate therapy.

Persistence of gestational diabetes after childbirth occurs in $3-5 \%$ of cases. These data are congruent with the results of our research.

\section{REFERENCES}

1. Metzger BE, Coustan DR. Summary and recommendations of the Fourth International Workshop-Conference on Gestational Diabetes Mellitus. Diabetes Care 1998;21 (Suppl. 2):B161-B167

2. Moshe Hod, Anil Kapur, David A. Sacks, Eran Hadar Luis Cabero Roura, Harold David McIntyre, Jessica L.
Morris, Mukesh Agarwal, Gian Carlo Di Renzo, Hema Divakar. The International Federation of Gynecology and Obstetrics (FIGO) Initiative on gestational diabetes mellitus: A pragmatic guide for diagnosis, management, and care. I nternational Journal of Gynecology and Obstetrics 131 S3 (2015) S173-S

3. International Association od Diabetes and Pregnancy Study Groups Recommendations on Diagnosis and Classification od Hyperglycemia in Pregnancy. Diabetes Care 2012; 33:676-682.

4. Jiwani A, Marseille E, Lohse N, Damm P, Hod M, Kahn JG. Gestational diabetes mellitus: results from a survey of country prevalence and practices. J Matern Fetal Neonatal Med 2012;25(6):600-10

5. World Health Organization. Obesity and overweight. Fact sheet $\mathrm{N}^{\circ} 311$. http:// www.who.int/mediacentre/ factsheets/fs311/en/. Updated January 2015. Accessed March 202014.

6. International Diabetes Federation. IDF Atlas. Sixth Edition. Brussels, Belgium: International Diabetes Federation; 2013.

7. Kessous R, Shoham-Vardi I, Pariente G, Sherf M, Sheiner E. An association between gestational diabetes mellitus and long-term maternal cardiovascu- lar morbidity. Heart 2013;99(15):1118 -21.

8. Cheung NW, Byth K. The population health significance of gestational diabetes. Diabetes Care. 2013;26:2005-2009.

9. Albareda M, Caballero A, Badell G, Piquer S, Ortiz A, de Leiva A, et al. Diabetes and abnormal glucose tolerance in women with previous gestational diabetes. Diabetes Care 2003;26:1199-1205.

10. "Bird” Hoffert Gilmartin, Serdar H. Ural, MD, John T. Repke, Gestational Diabetes Mellitus Rev Obstet Gynecol. 2008;1(3):129-134.

11. Canadian Diabetes Association 2008. Clinical Practice Guidelines for the Prevention and Management of Diabetes in Canada. Gestational diabetes mellitus. Diabetes and Pregnancy. Can J Diabetes. 2008; 32(Suppl 1):S168-S180.

12. Hapo Study Cooperative Research Group. Hyperglycaemia and adverse pregnancy outcomes. N Eng J Med. 2008;358:1991-2002.

13. Jović N., Varjačić M., Nenadović Živanović A., „Da li blizanačka trudnoća postaje apsolutna indikacija za carski rez?", zbornik radova, str. 157-165, LVIII GAN GAS SLD, Beograd, 2014. godine 
อ 